\title{
Architect Critical Challenges as a Project Manager in Construction Projects: A Case Study
}

\author{
Mohammadreza Yadollahi, ${ }^{1}$ Mohammad Mirghasemi, ${ }^{2}$ \\ Rosli Mohamad Zin, ${ }^{3}$ and Bachan Singh ${ }^{1}$ \\ ${ }^{1}$ Faculty of Civil Engineering, Universiti Teknologi Malaysia, 81310 Skudai, Johor, Malaysia \\ ${ }^{2}$ Faculty of Built Environment, Universiti Teknologi Malaysia, 81310 Johor, Malaysia \\ ${ }^{3}$ Construction Research Centre, Universiti Teknologi Malaysia, 81310 Johor, Malaysia \\ Correspondence should be addressed to Mohammadreza Yadollahi; mohammadreza@utm.my
}

Received 15 May 2014; Revised 15 July 2014; Accepted 15 July 2014; Published 13 August 2014

Academic Editor: Hossein Moayedi

Copyright (C) 2014 Mohammadreza Yadollahi et al. This is an open access article distributed under the Creative Commons Attribution License, which permits unrestricted use, distribution, and reproduction in any medium, provided the original work is properly cited.

\begin{abstract}
All construction professionals such as civil, mechanical, and electrical engineers, quantity surveyors, and architects have important roles in the construction process. Among these, architects are frequently appointed as a project manager (PM). The role of a PM will drive the success of the projects implementation. Therefore, the capability of an architect as a PM (ArPM) is critical in reducing challenges encountered. Accordingly, the identification of these challenges is an important task in selecting an appropriate ArPM. The aim of this study is to identify the most critical challenges faced by an ArPM for construction projects. The data were collected through questionnaires and interviews with architects and professionals in the Malaysian construction industry. Because of the fuzziness and uncertainty of subjective responses, Fuzzy Set Ttheory is applied to identify critical challenges. A total of 65 questionnaires were distributed and 36 questionnaires were returned. The results revealed that the critical challenges faced by an ArPM are "poor planning," "unfamiliar technology," "unfamiliarity with green buildings and materials," "inappropriate scheduling," and "poor workmanship." All critical challenges were then categorized into six main groups including technical, managerial, personal skills, contractual, psychological, and financial.
\end{abstract}

\section{Introduction}

The construction industry inherently has many different problems and requirements [1]. The importance of taking measures to improve the performance of the construction industry at various levels of socioeconomic development has been recognized in many countries. While the construction industry everywhere faces problems and challenges, the complexities and difficulties are most critical in developing countries due to the general situation of socioeconomic issues, lack of resources, organizational weaknesses, and an inability to deal with critical situations. According to the Singapore Department of Building [2], there is evidence that the problem has become greater in extent and severity in recent years.
In Malaysia for instance, building construction accounts for about $67.6 \%$ of overall construction work and is considered to be an essential element of the industry [3]. Due to existing limitations such as unavailability or lack of technical and/or financial resources, Malaysia faces some challenges in local projects. Moreover, external factors, for example, prohibition to engage in commercial activities, political pressure to suddenly increase the volume of mass projects, and complex or difficult land conditions, may also complicate the problem [4].

Generally, there are some important elements for the successful management of a construction project such as project management philosophies, processes, methods, and tools; however, one important factor in this field is the capability of the project manager (PM). Finding the right PM 
for a construction project is the most important commercial implementation task. Selecting a capable PM is an essential element to achieve success in a construction project. However, PMs have a variety of personal characteristics based on their beliefs, experience, personal values, professional ethics, technical knowledge, superior social skills, and their management abilities [5]. In this regard, initial studies on architecture challenges were published during the 1960s [6]. According to Tan [7], most PMs come from a wide range of professional disciplines in developing countries. Consequently, not one person from a single profession can claim to be a perfect PM. In some countries, there are no guidelines or standards that provide for a better selection of PMs to ensure excellent performance in the construction industry. However, certain organizations such as the Project Management Institute (PMI) have submitted their Strategic Overview of Project Management practices to the Construction Industry Development Board (CIDB) and recommended general directions to improve the service for the benefits of the governmental sector [8].

Construction project abandonment has been frequently reported in many countries such as the United States [9], Spain [10], United Arab Emirates, Saudi Arabia, Qatar, Bahrain, Kuwait, and Russia [11]. Although the reducing trend shows satisfactory results, the Ministry of Housing and Local Government reported that the lack of having the competent PMs and mismanagement are still critical problems in Malaysian construction industry, such that 514 and 95 abandoned housing projects were reported in 2000 and 2012, respectively, [12-15]. From the records, it is shown that nearly $90 \%$ of abandoned projects were caused by management problems faced by the developer [15]. Only a few of the causes are due to technical matters and failure in the company's performance. The statistics also reveal that one of the main reasons for project failures in Malaysia and many other developing countries is the lack of a proper architect as a PM (ArPM), as an agreeable and competent manager with appropriate plans and point of view [16]. Malaysian standard form of building contract [17] enumerates some of the most important points that ArPM has to consider to face fewer challenges and be successful in construction projects including clear contract and communication, proper planning and monitoring, and also special skills to lead and handle problems at construction sites. This study specifically focuses on the identification of the most critical challenges that the architect may face as a PM in Malaysia as a developing country. Despite wide discussion in the literature regarding the importance of the role of PMs and architects in construction projects, few prior studies have identified the critical challenges facing an architect as a project manager.

\section{Architect as a Project Manager (ArPM)}

Project management is the direction and supervision of a project by the use of specific tools and control techniques including cost control, manpower, time, plant/machineries, communication, and motivation [46]. According to Wideman [47], "project management is the art of directing and coordinating human and material resources to achieve stated objectives within limits of time, budget, and stakeholders' satisfaction." PMs have total responsibility in construction sectors such as planning, organizing, and controlling. They are responsible for making sure that the planning phase of a project contains complete task definition, resources, time schedule, and a list of requirements. Furthermore they organize the project to make sure of hiring competent staff in order to produce necessary services and to achieve project objectives.

Many studies have mentioned the critical prerequisite skills for a PM [48, 49]. In this regard, Ahadzie [50] had investigated the relationship between achieving project success and construction project management competencies. Successful construction organizations now focus on ensuring that PMs obtain the principal competencies that they require to be successful in their jobs. According to Frank [51], the PM has direct authority over 34-47\% of a project's success. Accordingly, it is clear that a PM plays a key role in achieving success for a construction project. The relationship between client, developer, and/or investor and the rest of the project's construction team is also significant.

PMs play significant roles in the process of a construction/rehabilitation project. A PM with adequate experience, supported by a group of qualified professional and clerical staff, will head the project and be responsible for the dayto-day implementation of project activities. A PM and his team should have training in management aspects [52]. PMs should be approved and accepted by project stakeholders to have adequate experience for heading the project implementation and be responsible for the supervision of specific implementation activities. In maintenance/retrofit projects for instance, various proposals for rehabilitation activities are presented to PMs in the form of project proposals. Accordingly, one challenge facing project managers and decision makers is to select the most vulnerable structures [53]. In this regard, the creation of alternatives for the renovation or rehabilitation of every project is mainly incumbent on the PMs [54]. Hegazy [55] also mentioned that it is the objective of PMs to optimize the allocation and leveling aspects of the project resources.

While PMs play important roles in the construction industry from the design stage to implementation and demolition, most employers and clients have paid little attention to the performance of the architects in construction projects. They would rather concentrate on the performance of contractors. Recently, the construction industry has integrated the architect as a manager with executive power on the site [56]. The performance of the architect is therefore important, because any decision made at the inception of the project will affect the project's success. In brief, although the construction industry faces many challenges such as delays, cost overruns, fluctuation in the price of materials, and breaches of duty, all of these challenges are directly related to the relationship between the ArPM and client.

\section{Responsibilities and Skills of ArPM}

According to Odusami [57], skill is defined as "an ability that can be developed which is manifested in performance." 
In other words, skills are the knowledge and abilities you gain throughout your life. Due to the quickly changing environment of the construction industry with emerging challenges such as skills shortages, the rapid advancement of information and communication technologies, and the increasing prioritization of issues such as sustainability, environmental protection, and climate change, the role of the PM needs to be adapted. Widespread research studies have documented that managerial skill is necessary for efficient project performance [57].

Generally, the construction manager has a challenging role to perform and must manage a wide variety of works on site. The project manager's CADD survival guide [58] describes the duties and responsibilities of PMs with the basic management components such as project control, project administration, financial control, client relations, business development, design production, team management, and quality assurance [58]. According to the Malaysian governmental form of contract [17], the construction PM has an obligation to serve the owner and also has right and authority to represent the owner and to carry out business on their behalf. Additionally, he/she has the right to choose contractors and manage the relationship between the contractor, owner, and staff.

All ArPMs have four main duties: leading, organizing, controlling, and supervising. Each function plays an essential role during the construction project. Indeed, ArPMs have to consider all steps from the design stage till the demolition. In the planning stage, they must act as a forecaster in order to predict and provide the following requirements: (i) establish aims and goals, (ii) organize activities to achieve goals, and (iii) monitor budget and time. Secondary skills are the organization of resources such as time, cost, manpower, and machinery and equipment to effectively approach the project aims. Another responsibility of the ArPMs is project control. Control processes measure progress against goals and evaluation activities and when to take corrective action. This skill ensures managers that all parts of the project are completed according to the contract, design, drawing, specification, and details of the architect. Finally, in the supervision step, all of the activities must be supervised during the project to prevent any defects in construction.

To standardize the ArPM required qualifications, the Project Management Institute (PMI) first documented nine knowledge areas: integration, time, cost, procurement, quality, communication, human resource, scope, and risk [56]. Each of the nine knowledge areas contains processes that need to be accomplished within its discipline in order to achieve an effective project management program. B. G. Fryer and M. Fryer [59] also listed social skills, decisionmaking skills, problem-handling skills, ability to recognize opportunities, and management of changes as key personal attributes affecting project success. It is explicitly clear that the role of today's PMs has changed. Some authors imply that PMs must supplement their traditional functions with nonengineering knowledge and skills in order to meet today's professional demands [60]. Today's PMs not only fulfill the traditional roles of project management but also must manage the project in the most efficient and effective manner with respect to sustainability. The former emphasizes workers' attributes such as knowledge, skills and abilities, and personal traits, while the latter treats work as existing independently of the worker, definable in terms of the technical requirements of the work [61].

Effective job performance is influenced by different characteristics of the competences such as behaviors and trait [62]. Crawford [49] provided an indepth understanding of the subject by proposing three classifications, namely, input competencies, personal competencies, and output competencies. He implied that input competencies refer to the knowledge and skills that a person brings to a job. In this regard, Majid et al. [46] categorized the PMs according to their skill levels into competent, excellent, and great. He also implied that a competent PM has the necessary knowledge, skill, and experience, an excellent PM has more skills beyond those individual characteristics, and a great PM has two additional skills, the motivation and natural talent to lead.

Consequently, the role and responsibilities of architects in the construction site are to handle the project efficiently and to overcome any challenges in its implementation. Failure on the part of the architect during the conceptual planning and design stage might lead to stress factors that cause significant problems in successive stages of the project. ArPM must have various required skills such as detail planning, scheduling and construction estimation of operating procedure, supervision, inspection and testing, plan and submittal review, property management, and correspondence. The workmanship of the ArPMs and their skills in terms of design and project management implementation are definitely one of the most significant factors in achieving the goals of a construction project. All of the abovementioned skills can be applied to motivate project employees, forecast conditions, control and supervise tasks, and manage resources.

\section{Challenges of ArPM at Construction Sites}

A construction PM should consider everything in order to prevent failure in any step of the project. However, in most cases, undesirable challenges exist in project implementation.

Generally, the implementation of any new system or a change in initiatives has always been a challenging task; some of these challenges can occur during the implementation or the practice stage of a project. Due to a lack of clarity surrounding program management in the construction industry, an understanding of the major challenges facing a project remains vague. Milosevic et al. [21] stated that a fair amount of confusion exists among organizations about what program management stands for, and there is a lack of sufficient literature to accurately describe it [20]. In addition, Young [23] mentioned that economic fluctuations, population and migration growth, and growing pressure from global economic instability are the general characteristics of the construction industry environment. Accordingly, program management is aimed at exchanging timely and useful information with stakeholders or work teams. Therefore, lack of cross-functional communication can be another major challenge for ArPM in managing a construction program. 
Specifically, one of the significant challenges that architects are facing concerns their skills and ability to manage and handle problems, which has not been mentioned directly in previous studies. The ArPM has to be both skilled and knowledgeable in order to overcome challenges that they would encounter during the design stage or implementation stage. Lack of sufficient skills or knowledge will lead to poor communication that weakens the relationship between both PM and contractors and between PM and clients. Therefore, to avoid additional challenges on construction sites, a competent manager has to have the necessary skills to negotiate with clients and to create binding agreements. In brief, proper selection of a PM can allow the completion of a project within deadlines and a high standard of quality [63]. In terms of having the essential skills to overcome the challenges a PM may face in working closely with a range of other professionals, PMs organize, plan, schedule, and control the work of their subordinates. Moreover, completing the project within the time and cost constraints are the main responsibilities of the PMs [64].

Siva and London [38] implied that the relationship between employees and architect is important. According to Hewage et al. [65], over $45 \%$ of construction workers described communication problems between the managers and the workers; this inadequate communication clearly results in adverse impacts on the productivity of the workforce.

Construction PMs are generally considered to be the key in the success of a construction project. Their role includes not only planning, organizing, and supervising the project team and the progress of work on the construction project, but also overcoming and dealing with demanding time pressures, inherent uncertainties, and complexity in the structure. The stressful environment of a construction project may reduce the potential capability of the PM. According to a recent occupational stress study in the construction industry, nearly $70 \%$ of construction professionals suffer from stress, anxiety, or depression [3]. The impacts of stress on construction professionals should be seriously taken into consideration. An environment that causes stress ultimately causes challenges in the construction industry project implementation and resource management [18].

Apart from the specific challenges faced by ArPM, factors such as increases in the scope and complexity of the structure as well as the active systems for its infrastructure and buildings, integrated project delivery and building information modeling, inadequate design, and poor planning may also create additional challenges in the completion of a construction project [39].

According to Bertelsen et al. [66], an architect's incompetence in project management systems, especially at the briefing stage of the building process, may result in the poor coordination and supervision of the design team. Another challenge as described by Khoury [67] is the separation of the architectural design from systems design and engineering which has often occurred because of rapid changes in the design processes. The criticality of the performance of ArPM in relation to public and private sector is another issue. In this regard, Adinyira and Dafeamekpor [68] evaluated the clients' perception of the performance of architects in building projects. According to NCARB [69], the involvement of the ArPMs should be continued until and even after the completion of the construction documents.

Based on a critical literature review of the important role of PMs and ArPMs in construction projects, which were discussed in the previous sections, it is found that many efforts have been made to highlight different aspects of PMs. Although existing studies have argued and emphasized the importance of selecting the appropriate PM in construction/rehabilitation projects, critical challenges facing an architect as PM are still unavailable which presents a barrier to the effective assessment of the capabilities of an ArPM.

Project management philosophies, processes, methods, and tools are important components in successful project management; however, one of the most important elements is the capability of the PM. Finding the right PM for a construction project is therefore a major task in project implementation. Every owner, consultant, and contractor are on the lookout for a good project manager [70].

In Malaysia, there are no specific guidelines and standards that ensure a better selection of PMs for excellent performance in the construction industry. Project managers, more than any other individual, exert an immense influence over a project and can turn a potential success into an abject failure and a potential failure into a resounding success. Despite their influence, an unsuccessful project does not always indicate an unsuccessful PM. There are many external factors that cause a project to fail [71]. Truly, an unsuccessful project does not rely on the fault of a PM. But, the question is "how well do these project managers perform in the current construction industry?"

Accordingly, this study was carried out to investigate the challenges facing architects as project manager which are an essential part of the industry. More specifically, the aim of this study is to address the challenges of an ArPM in construction industry in general and in Malaysia, as developing country used as case study. Accordingly, there are two objectives: first, to investigate the conventional challenges of an ArPM in the Malaysian construction industry and, second, to identify the most critical challenges that have the greatest influence on a project's outcome. Data for analyzing the second objective was collected through a questionnaire survey.

\section{Research Methodology}

The first stage in the identification of the critical challenges facing an ArPM in Malaysia is to identify the most common and conventional challenges that exist in such projects in general. The identification process was implemented through the thorough study of official documents and existing feasibility study reports. The first stage led to the generation of a list of relative challenges that could be categorized into smaller groups. In addition, a few interviews and discussions (as a pilot study) provided valuable comments on the adequacy of the selection of the preliminary challenges, which were incorporated in the main questionnaire survey. In fact, the pilot survey conducted to test the adequacy and comprehensiveness of the identified challenges was done with the 
help of selected experts. This preliminary pilot survey with the help of member checking [72] approved the respondent validation through offering the respondents the opportunity to add further challenges or to put them on record to provide summaries and to check the adequacy of the survey.

Based on the generated list of challenges, a questionnaire survey was then conducted to collect data from the targeted respondents including Malaysian government agencies, building and project consultants, general contractors, and developers. In order to identify the critical challenges of an ArPM in Malaysian construction projects, the experts and professionals from selected organizations were targeted. The organizations include Malaysian government agencies, civil, structure, and building consultants, project management consultants, and general contractors and developers. Coverage of such a variety of organizations was planned to represent the local construction industry in a comprehensive manner. The questionnaires were distributed among engineers and professionals in construction industry that would encounter and be familiar with the critical challenges in implementing a project in order to boost the quality and quantity of response.

5.1. Data Collection. The data for determining the level of significance of the identified challenges were collected through a questionnaire survey. A 5-point Likert scale was used to capture the preferences of respondents in the questionnaire for each identified challenge, where a level of " 5 " indicates the most important, "4" important, "3" average, "2" unimportant, and " 1 " negligible. In this survey, a group of 65 experts were asked separately to indicate an appropriate significance level from different Malaysian organizations. In total, 36 valid questionnaires were collected among different fields. Table 1 shows the profile of the respondents based on their type of organizations.

As the respondents were all selected from Malaysian construction industry and had knowledge of the research concerns, the responses were of good quality, and a high response rate was ensured. Among the responses, 4 were from government agencies, 6 were from general contractors, 7 were from project management consultants, 3 were from civil and structural consultants, and 16 were from architectural consultants.

5.2. Data Validity. One of the most important considerations when carrying out a questionnaire survey is the identification and selection of potential members to constitute the panel of experts. The selection of members or respondents is essential because the validity of the study is directly related to this selection process. Validity is a key aspect of scientific accuracy to ensure measuring the right thing and doing so properly. Without validity, there is little assurance that data is both relevant and accurate [73]. The validity of the postal questionnaire in this study is seen from two viewpoints: first, whether respondents who complete questionnaires do so accurately, honestly, and correctly and, second, whether those who fail to return their questionnaires would have given the same distribution of answers as did the returnees [74]. The question of accuracy can be checked by means of the interview method [75].

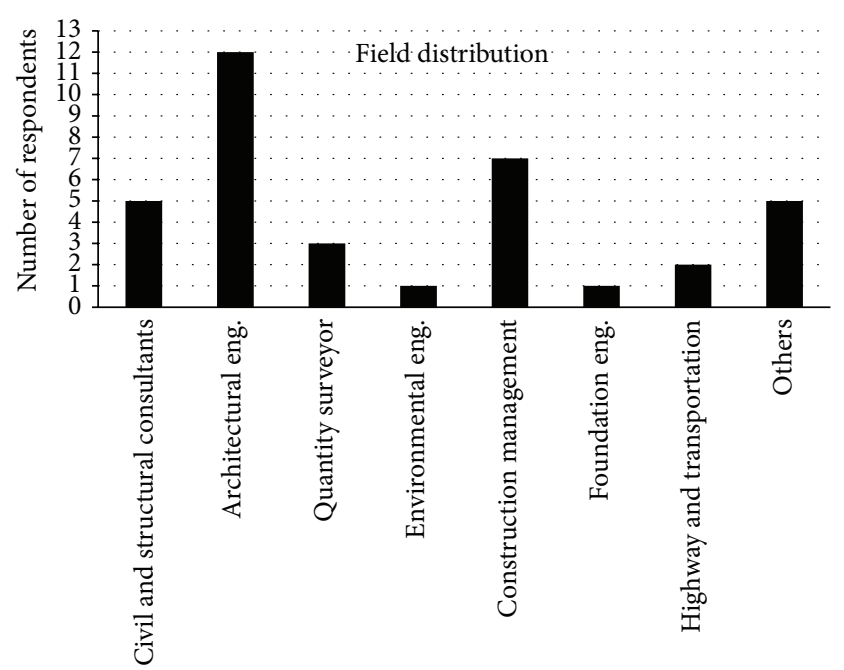

FIGURE 1: Type of work carried out by respondent's organizations (\# of respondents: 36 ).

In the current study, therefore, validity was checked through the feedback process and structured interviews with a few selected professionals. One obvious advantage of this feedback process is its ongoing consideration of the goal assumptions' validity. In total, thirty-six effective responses were received with a response rate of 55\%. According to Cohen et al. [75], a well-planned postal survey should obtain at least a 40-percent response rate without the judicious use of reminders. Therefore, the validity of the survey was seen. It was decided to categorize the respondents who have a direct interest and participation in the design and development of construction sites. The architectural engineer group includes the design professionals with a high rate of training and experience in design and an appreciation of the construction industry, particularly architecture. The professionals were randomly chosen and consisted of those who have had formal experience or training in any construction management process. The field distribution according to the type of organization is shown in Figure 1.

5.3. Identification of Critical Challenges Based on Fuzzy Set Theory. The concept of fuzziness and the application of Fuzzy Set Theroy in data analysis were first introduced by Bellman and Zadeh [76] to deal with subjectivity and uncertainties. This is a strong and widely applicable theory for many fields of science and design including engineering, agriculture, medicine, and social science. This theory helps to identify the critical elements amongst all identified challenges. The main reason to apply this theory is because of fuzziness and uncertainty in subjective responses due to imprecision or vagueness [77]. In the current study, because of subjective and qualitative terms of the data in determining the significance of challenges, implementing this theory is beneficial [78].

Statistical calculations were conducted to determine the significance of critical challenges in the construction industry. Mean scores (MS) and standard deviations (SD) are determined for all challenges. MS and SD provided the basic data 
TABLE 1: Respondents profile.

\begin{tabular}{lcccccc}
\hline Organization & $\begin{array}{c}\text { Government } \\
\text { agencies }\end{array}$ & Landlords & $\begin{array}{c}\text { General } \\
\text { contactors }\end{array}$ & $\begin{array}{c}\text { Project management } \\
\text { consultants }\end{array}$ & $\begin{array}{c}\text { Civil and structural } \\
\text { consultants }\end{array}$ & $\begin{array}{c}\text { Architectural } \\
\text { consultancy }\end{array}$ \\
\hline $\begin{array}{l}\text { Number of } \\
\text { respondents }\end{array}$ & 4 & 0 & 6 & 7 & 3 & 16 \\
\hline
\end{tabular}

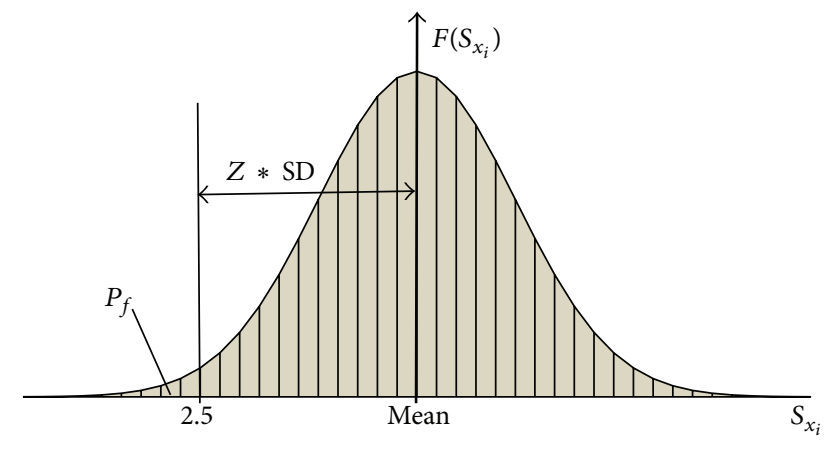

FIGURE 2: Normal distribution of challenges' significance score.

to which Fuzzy Set Theory was applied [79]. In the following paragraphs, the practical basis of this theory is described. For more details about the mathematical fundamentals of Fuzzy Set Theory, see Shen et al. [77] and Xia et al. [78]. According to Fuzzy Set Theory, the degree of membership is the probability of a variable belonging to a group [79] and is defined as follows [77]:

$$
\mu_{\widehat{A}}\left(x_{i}\right)=\int_{5}^{\infty} F\left(S_{x_{i}}\right) d_{x}=1-P_{f}
$$

where $\mu_{\widehat{A}}\left(x_{i}\right)$ is the degree of membership for each challenge in each category and $P_{f}$ is the possibility that a challenge does not belong to the group of critical ones. The $Z$ parameter is defined as the calculated value for whether or not a challenge is included in final set. Figure 2 shows the graphical illustration of the $Z$ parameter. This variable is determined for each challenge with the help of the following equation:

$$
Z=\frac{\text { Mean }-2.5}{\mathrm{SD}}
$$

The degree of membership for the respondents is estimated as follows:

$$
\mu_{A}\left(x_{i}\right)=\min \left\{1, \mu_{A}(x)\right\} .
$$

In this equation, $\mu_{A}\left(X_{i}\right)$ are the degrees of membership for each challenge. To identify critical challenges amongst the other challenges, the $\lambda$-cut set approach is adopted [77]. The $\lambda$-cut set method can be used to transfer a fuzzy set to a classical set. The optimal outcome is $\lambda=1$ and the worst outcome is $\lambda=0$. For this study, $\lambda=0.85$ was adopted in order to identify the critical challenges $[77,80]$. Figure 3 illustrates the flowchart for the procedure used to identify the critical challenges.

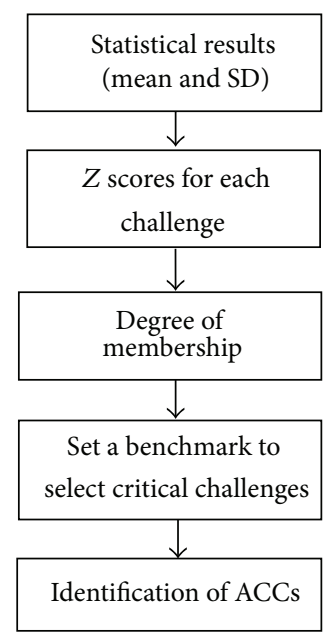

Figure 3: The Fuzzy Set Theory procedure to identify ACCs.

\section{Results and Discussion}

This section describes the findings of analysis regarding the most critical factors that the Malaysian ArPMs encounter in both the evaluated literature and their projects. During the first stage, a comprehensive literature review for finding the challenges was carried out. This section led to the introduction and identification of all ArPM challenges that had the greatest effects on goals of a project such as time, cost, and quality. 41 challenges were identified in the first stage. Table 2 shows the results of identifed challenges and their relative codes and descriptions for further analysis. It is to be noted that the identified challenges were revised and combined where possible.

As previously mentioned, the data used for this study was collected through a questionnaire survey from targeted Malaysian experts. The adequacy and readability of the questionnaire were also tested with a pilot study. Five experts were involved in the pilot study, and their comments were incorporated into the final questionnaire. In responding to the questionnaire, respondents were invited to indicate the level of significance of each assessment indicator for indicating the most critical challanges faced by architects in a project by assigning a score between 1 and 5. However, the fuzziness involved in the experts' opinions should be considered. Fuzzy Set Theory is a practical approach in this regard to capture the fuzziness in the questionnaire survey date; the calculations are detailed in Table 3.

Architects have a variety of responsibilities within the construction and maintenance process. The questions in the survey were rated by the respondents to identify which 
TABLE 2: Summary of literature review regarding the identification of ArPM challenges.

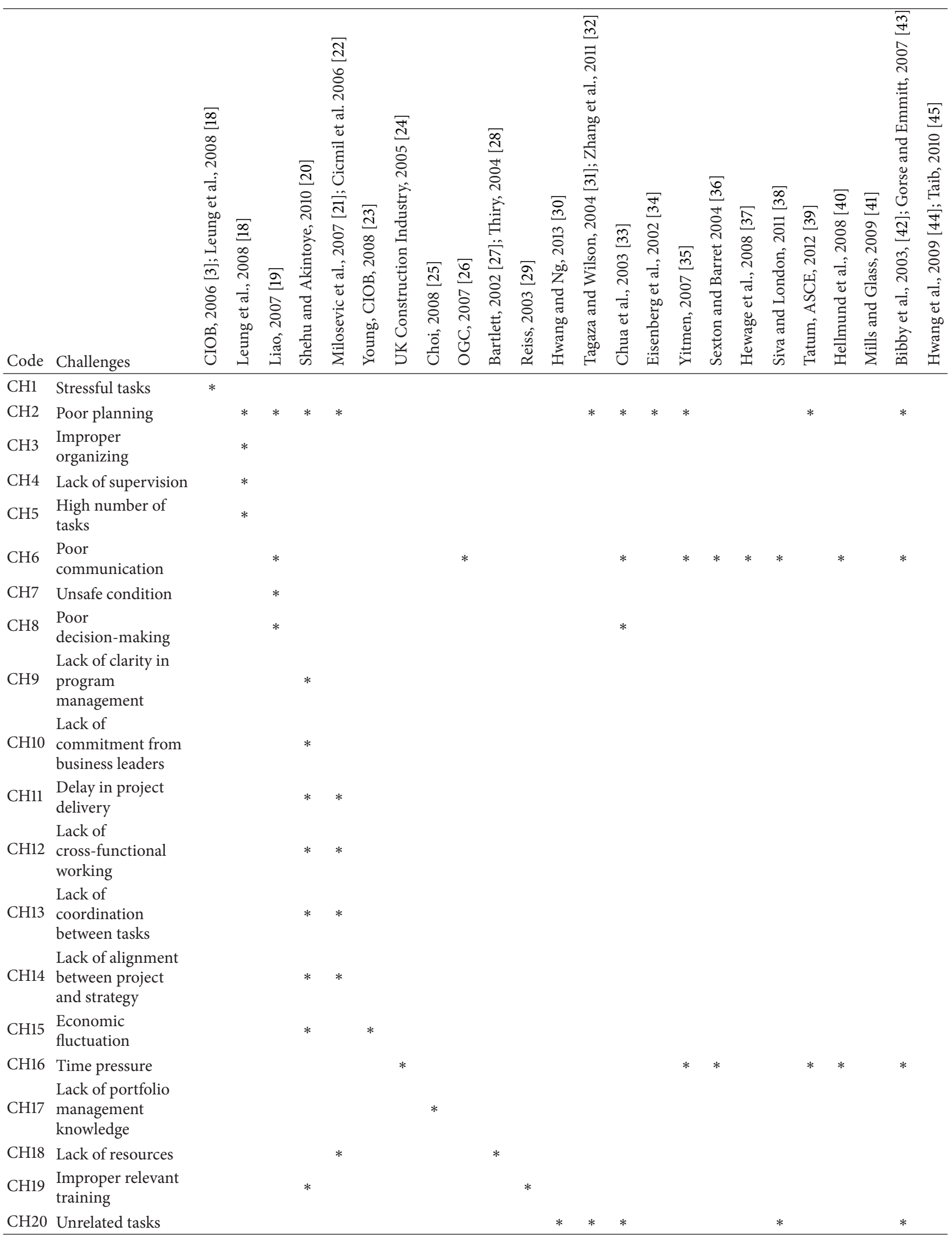


TABle 2: Continued.

\begin{tabular}{|c|c|c|c|c|c|c|c|c|c|c|c|c|c|c|c|c|c|c|c|c|c|c|c|c|c|}
\hline Code & Challenges & 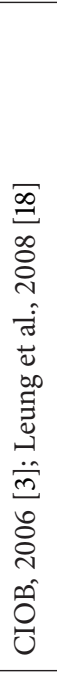 & 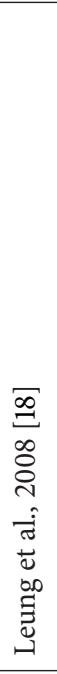 & 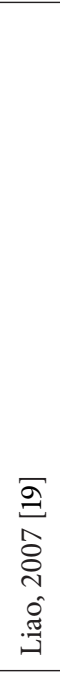 & 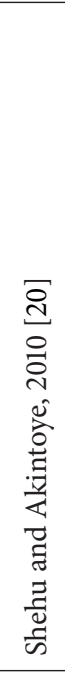 & 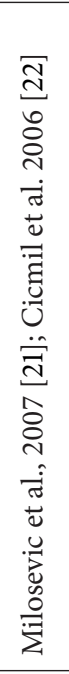 & 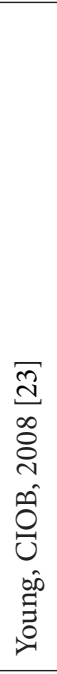 & 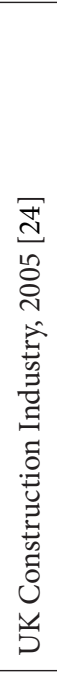 & 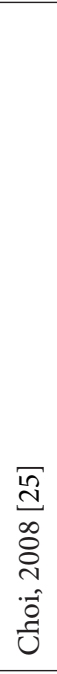 & $\begin{array}{l}\text { D } \\
\text { N } \\
\hat{0} \\
\text { D } \\
\text { in } \\
0 \\
0 \\
0\end{array}$ & 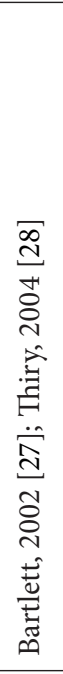 & 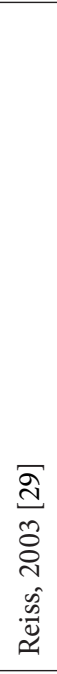 & 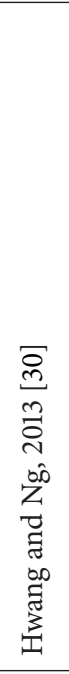 & 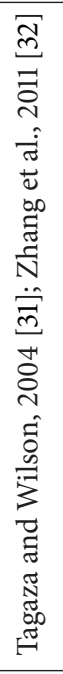 & 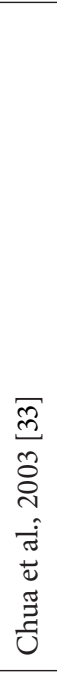 & 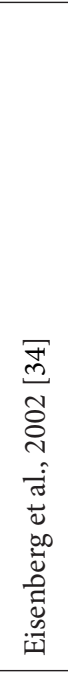 & 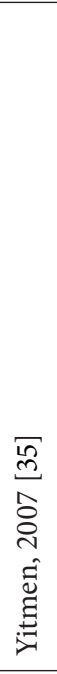 & 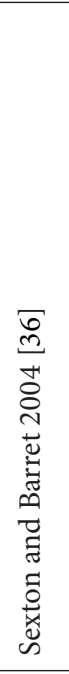 & 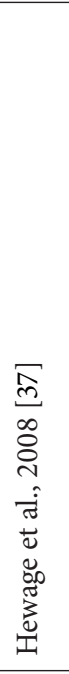 & 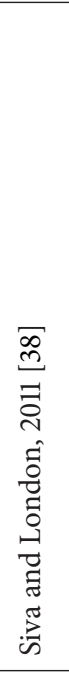 & 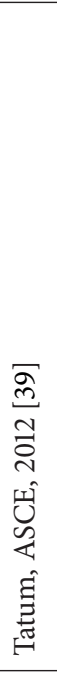 & 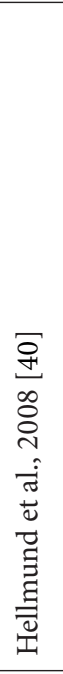 & 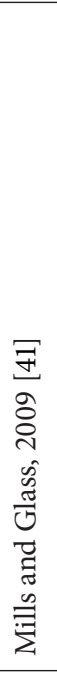 & 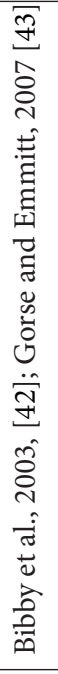 & 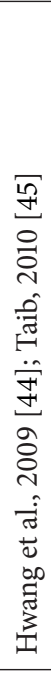 \\
\hline $\mathrm{CH} 21$ & $\begin{array}{l}\text { Complexities in } \\
\text { construction } \\
\text { process }\end{array}$ & & & & $*$ & & & & & & & & & & $*$ & & & & & & $*$ & & & & \\
\hline $\mathrm{CH} 22$ & $\begin{array}{l}\text { Conflicting project } \\
\text { objectives }\end{array}$ & & & & $*$ & & & & & & & & & & & & & & $*$ & & & & & & \\
\hline $\mathrm{CH} 23$ & $\begin{array}{l}\text { Fuzzy companies } \\
\text { strategy }\end{array}$ & & & & $*$ & & & & & & & & & & & & & & & & & & & & \\
\hline $\mathrm{CH} 24$ & $\begin{array}{l}\text { Discrepancy in } \\
\text { contract forms }\end{array}$ & & & & & & & & & & & & & * & $*$ & & & & & & & & & & \\
\hline $\mathrm{CH} 25$ & $\begin{array}{l}\text { Unfamiliar } \\
\text { technology }\end{array}$ & & & & & & & & & & & & & $*$ & & $*$ & & & * & & * & & & & \\
\hline $\mathrm{CH} 26$ & $\begin{array}{l}\text { Unfamiliarity with } \\
\text { Green building and } \\
\text { materials }\end{array}$ & & & & & & & & & & & & & $*$ & & $*$ & & & & & & & & & \\
\hline $\mathrm{CH} 27$ & $\begin{array}{l}\text { Inappropriate } \\
\text { construction } \\
\text { sequence }\end{array}$ & & & & & & & & & & & & & & $*$ & & $*$ & $*$ & & & & & & $*$ & \\
\hline $\mathrm{CH} 28$ & $\begin{array}{l}\text { Difficulty in the } \\
\text { selection of } \\
\text { subcontractor }\end{array}$ & & & & & & & & & & & & & & $*$ & & & & & & & & & & \\
\hline $\mathrm{CH} 29$ & Design alteration & & & & & & & & & & & & & & $*$ & & & & & & & & & & \\
\hline $\mathrm{CH} 30$ & High level of risk & & & & & & & & & & & & & & $*$ & & & & & & & & & & \\
\hline CH31 & $\begin{array}{l}\text { Worker's } \\
\text { unawareness }\end{array}$ & & & & & & & & & & & & & & $*$ & & & & * & & & & & & \\
\hline $\mathrm{CH} 32$ & Government policy & & & & & & & & & & & & & & $*$ & & & & & & & & & & \\
\hline CH33 & $\begin{array}{l}\text { Unforeseen } \\
\text { circumstances }\end{array}$ & & & & & & & & & & & & & & $*$ & & & & & & & & & & \\
\hline $\mathrm{CH} 34$ & Lack of trust & & & & & & & & & & & & & & & & $*$ & $*$ & & $*$ & & & & & \\
\hline CH35 & Unclear contract & & & & & & & & & & & & & & & & $*$ & $*$ & & & & & $*$ & $*$ & \\
\hline CH36 & $\begin{array}{l}\text { Inappropriate } \\
\text { performance } \\
\text { measurement }\end{array}$ & & & & & & & & & & & & & & & & $*$ & & & & & & & & \\
\hline CH37 & $\begin{array}{l}\text { Nonintegrated } \\
\text { project delivery }\end{array}$ & & & & & & & & & & & & & & & & & & * & & $*$ & $*$ & $*$ & * & \\
\hline CH38 & Poor specification & & & & & & & & & & & & & & & & & & & & & & & & $*$ \\
\hline CH39 & $\begin{array}{l}\text { Inappropriate } \\
\text { scheduling }\end{array}$ & & & & & & & & & & & & & & & & & & & & & & & & $*$ \\
\hline $\mathrm{CH} 40$ & Poor workmanship & & & & & & & & & & & & & & & & & & & & & & & & $*$ \\
\hline CH41 & $\begin{array}{l}\text { Inadequate } \\
\text { payment }\end{array}$ & & & & & & & & & & & & & & & & & & & & & & & & $*$ \\
\hline
\end{tabular}


TABLE 3: Statistical analysis to identify ACCs based on Fuzzy Set Theory.

\begin{tabular}{|c|c|c|c|c|c|}
\hline Code & MS & SD & $Z$ scores & $\mu(x i)$ & ACCs \\
\hline CH1 & 1.40 & 0.55 & -2.01 & 0.02 & - \\
\hline $\mathrm{CH} 2$ & 3.80 & 0.45 & 2.91 & 1.00 & $\checkmark$ \\
\hline $\mathrm{CH} 3$ & 2.40 & 0.55 & -0.18 & 0.43 & - \\
\hline $\mathrm{CH} 4$ & 2.60 & 0.55 & 0.18 & 0.57 & - \\
\hline CH5 & 3.20 & 0.45 & 1.57 & 0.94 & $\checkmark$ \\
\hline $\mathrm{CH} 6$ & 4.23 & 0.87 & 1.99 & 0.98 & $\checkmark$ \\
\hline $\mathrm{CH} 7$ & 2.60 & 0.89 & 0.11 & 0.54 & - \\
\hline $\mathrm{CH} 8$ & 3.80 & 0.84 & 1.55 & 0.94 & $\checkmark$ \\
\hline $\mathrm{CH} 9$ & 3.20 & 0.84 & 0.84 & 0.80 & - \\
\hline CH10 & 1.60 & 0.55 & -1.64 & 0.05 & - \\
\hline CH11 & 3.40 & 0.55 & 1.64 & 0.95 & $\checkmark$ \\
\hline $\mathrm{CH} 12$ & 3.80 & 0.84 & 1.55 & 0.94 & $\checkmark$ \\
\hline CH13 & 2.80 & 0.45 & 0.67 & 0.75 & - \\
\hline $\mathrm{CH} 14$ & 2.40 & 0.55 & -0.18 & 0.43 & - \\
\hline $\mathrm{CH} 15$ & 2.00 & 0.71 & -0.71 & 0.24 & - \\
\hline CH16 & 4.20 & 0.84 & 2.03 & 0.98 & $\checkmark$ \\
\hline CH17 & 4.20 & 0.84 & 2.03 & 0.98 & $\checkmark$ \\
\hline CH18 & 4.05 & 0.72 & 2.14 & 0.98 & $\checkmark$ \\
\hline CH19 & 2.80 & 0.45 & 0.67 & 0.75 & - \\
\hline $\mathrm{CH} 20$ & 4.09 & 0.97 & 1.64 & 0.95 & $\checkmark$ \\
\hline $\mathrm{CH} 21$ & 2.00 & 0.71 & -0.71 & 0.24 & - \\
\hline $\mathrm{CH} 22$ & 1.40 & 0.55 & -2.01 & 0.02 & - \\
\hline $\mathrm{CH} 23$ & 3.00 & 0.71 & 0.71 & 0.76 & - \\
\hline $\mathrm{CH} 24$ & 3.82 & 1.10 & 1.20 & 0.89 & $\checkmark$ \\
\hline $\mathrm{CH} 25$ & 4.40 & 0.55 & 3.47 & 1.00 & $\checkmark$ \\
\hline $\mathrm{CH} 26$ & 4.60 & 0.55 & 3.83 & 1.00 & $\checkmark$ \\
\hline $\mathrm{CH} 27$ & 3.82 & 1.10 & 1.20 & 0.89 & $\checkmark$ \\
\hline $\mathrm{CH} 28$ & 2.80 & 0.84 & 0.36 & 0.64 & - \\
\hline $\mathrm{CH} 29$ & 4.09 & 0.75 & 2.12 & 0.98 & $\checkmark$ \\
\hline CH30 & 3.73 & 0.77 & 1.60 & 0.95 & $\checkmark$ \\
\hline CH31 & 3.95 & 0.95 & 1.53 & 0.94 & $\checkmark$ \\
\hline CH32 & 1.20 & 0.45 & -2.91 & 0.00 & - \\
\hline $\mathrm{CH} 33$ & 1.60 & 0.55 & -1.64 & 0.05 & - \\
\hline $\mathrm{CH} 34$ & 2.60 & 0.55 & 0.18 & 0.57 & - \\
\hline $\mathrm{CH} 35$ & 4.14 & 0.83 & 1.96 & 0.98 & $\checkmark$ \\
\hline $\mathrm{CH} 36$ & 3.40 & 0.55 & 1.64 & 0.95 & $\checkmark$ \\
\hline CH37 & 2.60 & 0.55 & 0.18 & 0.57 & - \\
\hline CH38 & 4.27 & 0.77 & 2.31 & 0.99 & $\checkmark$ \\
\hline CH39 & 4.32 & 0.65 & 2.81 & 1.00 & $\checkmark$ \\
\hline $\mathrm{CH} 40$ & 4.41 & 0.50 & 3.79 & 1.00 & $\checkmark$ \\
\hline $\mathrm{CH} 41$ & 4.18 & 1.01 & 1.67 & 0.95 & $\checkmark$ \\
\hline
\end{tabular}

challenges have the greatest influence on the projects outcome with respect to the perception of time, cost, and quality. These are the main parameters in planning and managing a successful construction project [81]. Inappropriate identification and selection of an ArPM may lead to poor planning which directly affect determining, analyzing, devising, and organizing the project resources. Subsequently, high alterations occurred in project outcomes in terms of
TABLE 4: Category 1: technical challenges.

\begin{tabular}{lcc}
\hline Code & Challenge & Degree of membership \\
\hline $\mathrm{CH} 25$ & Unfamiliar technology & 1.00 \\
$\mathrm{CH} 20$ & Unrelated tasks & 0.95 \\
\hline
\end{tabular}

time, cost, and quality. Therefore, the findings in this section can serve as a useful reference for construction practitioners and project managers, especially the architects, to revise the $\mathrm{PM}$ selection process and to avoid project challenges due to inappropriate selection of the PM.

The results reveal that the majority of the respondents believe that critical problems facing architects were "poor planning," "unfamiliar technology," "unfamiliarity with green buildings and materials," "inappropriate scheduling," and "poor workmanship" with $\mu\left(x_{i}\right)=1.00$ having the highest influence on project time, cost, and quality. Specific benefits that can be achieved from the identification of ACCs are a reduction in the time and cost of the project. Even though proper training, hiring, and managing architecture professionals may not prevent project delays and excessive overruns in terms of cost and time, such factors can be mitigated by construction projects stakeholders giving attention to the challenges facing the architect before the project even begins. 23 critical challenges were identified and ranked by the degree of membership in descending order which can be categorized in six general groups. These groups are discussed in more detail in the following sections. The findings can be useful for government construction legislators to revise the project manager regulations in order to reduce the number of failures in abandoned construction projects and save huge amount of budget in Malaysia.

6.1. Category 1: Technical. Three critical technical challenges are addressed in this category (see Table 4), including challenges associated with Unfamiliar Technology $(\lambda=1.00)$ and also Complexities in Construction Process $(\lambda=0.95)$. Technical challenge is defined by Katz [82] as lack of understanding and proficiency in a specific kind of activity, particularly one involving methods, processes, procedures, or techniques. It involves specialized knowledge, analytical ability within a specialty, and facility to use the tools and techniques of a specific discipline. A successful PM is one who possesses technical competence which has been gained through a career in an advanced technological environment. Furthermore, many researchers have mentioned technical challenges as the most important group of activities that can be challenging for an architect as a project manager [19, 38, $42,43]$, not to mention the fact that technical challenges is also one of the most critical challenges that architects may encounter and can cause the failure of a project $[18,32,39]$.

6.2. Category 2: Managerial. The challenges relevant to the management area consist of Inappropriate Scheduling $(\lambda=$ $1.00)$, Poor Specification $(\lambda=0.99)$, Design Alterations $(\lambda=0.98)$, Lack of Portfolio Management Knowledge $(\lambda=$ 0.98), Delays in Project Delivery $(\lambda=0.95)$, Inappropriate 
TABLE 5: Category 2: managerial challenges.

\begin{tabular}{lcc}
\hline Code & Challenge & $\begin{array}{c}\text { Degree of } \\
\text { membership }\end{array}$ \\
\hline $\mathrm{CH} 31$ & Inappropriate scheduling & 1.00 \\
$\mathrm{CH} 38$ & Poor specification & 0.99 \\
$\mathrm{CH} 29$ & Design alteration & 0.98 \\
$\mathrm{CH} 17$ & Lack of portfolio management knowledge & 0.98 \\
$\mathrm{CH} 11$ & Delay in project delivery & 0.95 \\
$\mathrm{CH} 36$ & Inappropriate performance measurement & 0.95 \\
$\mathrm{CH} 55$ & High number of tasks & 0.94 \\
$\mathrm{CH} 27$ & Inappropriate construction sequence & 0.89 \\
\hline
\end{tabular}

TABLE 6: Category 3: personal skill challenges.

\begin{tabular}{lcc}
\hline Codee & Challenge & $\begin{array}{c}\text { Degree of } \\
\text { membership }\end{array}$ \\
\hline $\mathrm{CH} 40$ & Poor workmanship & 1.00 \\
$\mathrm{CH} 2$ & Poor planning & 1.00 \\
$\mathrm{CH} 26$ & Unfamiliarity with green buildings and & 1.00 \\
$\mathrm{CH} 6$ & materials \\
$\mathrm{CH} 8$ & Poor communication & 0.98 \\
$\mathrm{CH} 31$ & Poor decision-making & 0.94 \\
$\mathrm{CH} 12$ & Worker's unawareness & 0.94 \\
\hline
\end{tabular}

Performance Measurements $(\lambda=0.95)$, High Number of Tasks $(\lambda=0.94)$, and also Inappropriate Construction Sequences $(\lambda=0.89)$. The degree of membership for CH39 (Inappropriate Scheduling) is 1.00; this illustrates the most critical factor in this category (see Table 5).

6.3. Category 3: Personal Skills. Category 3 illustrates the critical factors that are categorized as personal skill categories (see Table 6), including Poor Workmanship $(\lambda=1.00)$, Poor Planning $(\lambda=1.00)$, Unfamiliarity with Green Buildings and Materials $(\lambda=1.00)$, Poor Communication $(\lambda=0.98)$, Poor Decision-Making $(\lambda=0.94)$, Worker's Unawareness $(\lambda=$ 0.94), and Lack of Cross-Functional Working $(\lambda=0.94)$.

Personal characteristic and skills can be defined as the unique combination of the psychological traits we use to describe a person's workmanship, often called personality. Personality is defined as "the sum total of the physical, mental, emotional, and social characteristics of an individual" [83]. Disabilities in translating knowledge into action can be a great challenge. In others words, skills are the knowledge and abilities you gain throughout life. Some skills come almost naturally, while others come only by complete devotion to study and practice [84]. The degree of membership for $\mathrm{CH} 40$, $\mathrm{CH} 2$, and $\mathrm{CH} 26$ is 1.00 , which are the most critical factors.

6.4. Category 4: Contractual. Standard procedures and policies refer to the project manager's awareness of the recognition of the need for all aspects of an organization's operations to be consciously addressed and set down as a corporate statement in line with recognized standards, supported by
TABLE 7: Category 4: contractual challenges.

\begin{tabular}{lcc}
\hline Code & Challenge & Degree of membership \\
\hline CH35 & Unclear contract & 0.98 \\
CH24 & Discrepancy in contract forms & 0.89 \\
\hline
\end{tabular}

TABLE 8: Category 5: psychological challenges.

\begin{tabular}{lcc}
\hline Code & Challenge & Degree of membership \\
\hline CH16 & Time pressure & 0.98 \\
CH30 & High level of risk & 0.95 \\
\hline
\end{tabular}

systems appropriate to the achievement of the policy [16]. A procedure and contract are a series of related steps or tasks expressed in chronological order for a specific purpose. Contract and procedures define in a step-by-step fashion the methods through which policies are achieved. Contract emphasizes detail and policies which differ from the procedures because the purpose of policies is to help in the objective setting process. Therefore, contract and policies also create an understanding among members of a group that make the actions of each member more predictable to other members [33].

The project manager can rely to some extent on the policies and procedures developed by the organization. Thus, a lack of understanding or a lack of clarity in the contract could cause serious problems related to the organization and management of the tasks given to contractors [20, 33]. Regarding the contractual challenges (see Table 7), two factors are identified as critical challenges including Unclear Contract $(\lambda=0.98)$ and Discrepancy in Contract Forms $(\lambda=$ 0.89).

6.5. Category 5: Psychological. There are two critical psychological challenges (see Table 8 ) which were identified in this category, including challenges relevant to Time Pressure $(\lambda=$ $0.98)$ and also High Level of Risk $(\lambda=0.95)$. Psychological challenges are defined as the total activities, behaviors, and tasks that could be the cause of a stressor. Consequently, the stressor leads to the psychological stress of a person which disturbs activities of the organization [20,31-33].

6.6. Category 6: Financial. A lack of resources and inadequate finance from the client and payments for completed work during the construction stage are two common challenges found in most construction projects. In order for a project to be run efficiently and effectively by an architect as a project manager, management must provide sufficient resources in terms of labor, time, and money. Project management training shows how to define project needs and how to obtain approval upfront and helps project managers assign and prioritize resources throughout the duration of a project. To improve the chances of success from day one, an architect as project manager needs to be familiar with (i) how to approach their bank knowing exactly what they need in terms of finance, (ii) marketing their offering, (iii) managing their cash flow, preferably with a proper accounting system, 
TABLE 9: Category 6: financial challenges.

\begin{tabular}{lcc}
\hline Code & Challenge & Degree of membership \\
\hline CH18 & Lack of resources & 0.98 \\
CH41 & Inadequate payment & 0.95 \\
\hline
\end{tabular}

and (iv) working on generating a spread of small and big contractors, rather than focusing on one or two large ones.

Thus, in order to manage a whole project in terms of contractors, materials, time, and cost, the architecture has to control and manage the finances to prevent such challenging matters in construction sites such as delays, disputes, and dissatisfaction in the relationships with the landlord and contractors. Accordingly, competent architects have to mention and include these kinds of issues in their design, test, inspection, and executive managing on site in order to lead the project and accomplish its goals. Lack of Resources $(\lambda=0.98)$ and Inadequate Payment $(\lambda=0.95)$ were identified as the two critical challenges (see Table 9).

\section{Conclusion}

The understanding of architecture framework as project manager by public, organizational, and governmental sectors is significant in terms of reliable and effective adoption among clients. The purpose of this study is to help residential building project practitioners in the professional sectors to better choose project managers, provide information technologies that create progressive processes, improve decision-making, and create a competitive advantage from its adoption.

More specifically, this paper investigates the criticality of challenges that architects must tackle in construction projects by applying practical methods to analyze the data collected from questionnaire surveys. A group of 41 different challenges were identified through a review of the literature. Malaysian experts were then employed to revise the data and prioritize the criticality of the challenges according to their experiences. Because of the vagueness and impreciseness in the respondents' opinions, Fuzzy Set Theory was then applied to identify the most critical challenges for the Malaysian ArPMs. 23 critical challenges in six main groups were identified according to their degree of membership. These groups were technical, personal, managerial skills, contractual, psychological, and financial. In addition, the top six ACCs are identified as "unfamiliarity with green building and materials," "poor workmanship," "unfamiliar technology," "poor planning," "inappropriate scheduling," and "poor specification" with degree of membership of one.

Since it could be viewed in various perspectives, the authors of this paper highlight the importance of integrating the existing challenges and applications in the professional sector organizations in order to establish an efficient framework for landlords and architects. Therefore, support for essential skills and knowledge, its applications, and the necessary infrastructure technologies can be used to create a reliable and flexible method for construction projects to access competent architects by using government data and information transfers within and between organizations to aid in their identification and classification and support their control over a project as well as the necessary characteristics and managerial skills to lead a project to success. By using the identified weighted challenges, the architect framework illustrates the infrastructure components, applications, and technologies that can be used as guidelines for project adoption. However, the limitations of the method are appreciated such as the limited number of respondents, which requires a larger population of experts, and the appropriate selection of $\lambda$-set which has a direct effect on the critical challenges which need to be rectified. It is also suggested that in order to reduce or even completely solve the challenges facing ArPMs, further studies be conducted on the identification of the personal characteristics, skills, roles, and responsibilities in construction projects required by an ArPM. This can be facilitated by the development of software applications for the evaluation of ArPMs.

\section{Appendix}

\section{Definition of the ACCs}

CH2: Poor Planning. It involves the lack of having choice of technology, the definition of work tasks, the estimation of the required resources and durations for individual tasks, and the identification of any interactions among the different work tasks.

CH5: High Number of Tasks. High project task dependencies mean that certain tasks cannot begin unless another is completed. To handle such projects individually is difficult and sometimes impossible. The project should be divided among some different PMs.

CH6: Poor Communication. There are problems concerning communication with a focus on intrasupplier communication within the construction sector, demand-supply communication during the design phase, and communication between and within single demand and supply side parties, during the whole of the construction process [85].

CH8: Poor Decision-Making. It includes poor project governance, the lack of accountability of project stakeholders, and a lack of leadership.

CH11: Delay in Project Delivery. Delay is the time during which some part of the construction project has been extended or not performed due to an unanticipated circumstance [86].

CH12: Lack of Cross-Functional Working. Insufficient or inappropriate team working activities, functional diversity, competing identities, performance expectation, synergy, and integration with the construction organizations' structure will affect the future organizational strategy and development of the project. The PM is the leader of a cross-functional group comprising the project team assembled to successfully execute a set of project objectives. 
CH16: Time Pressure. A limitation period is the period of time within which a party to a contract must bring a claim. In construction contracts, limitation periods are often relevant in relation to defects claims brought against contractors [3].

CH17: Lack of Portfolio Management Knowledge. There is lack of project managers with the fundamental practices needed to achieve organizational results and excellence in the practice of project management [56].

CH18: Lack of Resources. There is shortage in having enough workers, money, machinery, time, and so on.

CH20: Unrelated Tasks. They are the responsibilities which are not relevant, pertinent, or associated with the architect and are asked of him/her to successfully manage simultaneously.

CH24: Discrepancy in Contract Forms. It is any conflict between tasks and written agreement that occurs during the construction [16].

CH25: Unfamiliar Technology. It is specified technology which the architect has never encountered before and should retain its associated risks; including unexpected design problems, uncertain risks, and overspending on the project.

CH26: Unfamiliarity with Green Building and Materials. It is architect's awareness about materials and processes that is environmentally responsible and resource-efficient throughout a building's life-cycle: design, construction, operation, maintenance, renovation, and demolition.

CH27: Inappropriate Construction Sequence. It is improper describing of the sequence of the activities and the significant tasks interdependencies required to meet the project scope of work.

CH29: Design Alteration. It is any conflict, differences, or changes of design during the period of construction that may change basic tasks [16].

CH30: High Level of Risk. It is a project critical strategic importance and large budget and high complexity.

CH31: Worker's Unawareness. It is employees with low level of training and awareness in terms of construction tasks.

CH32: Unclear Contract. It is greement with any irrelevant or fuzzy clause, condition, and specification that may cause some challenges during the construction tasks.

CH36: Inappropriate Performance Measurement. It is lack of knowledge in assessment value procedure of essential performance parameters of the current project through engineering analysis and tests.

CH38: Poor Specification. It is lack of specifications to clarify and advise the contractor of his responsibility to perform all of the work and services as outlined in construction tasks Department of Public Work, Dartmouth, Massachusetts,
Construction Specifications, 2009, http://www.town.dartmouth.ma.us/Pages/DartmouthMA_DPW/Con.pdf.

CH39: Inappropriate Scheduling. It is ineffective, unrealistic, and impossible project time estimation for project's milestones, activities, and deliverables.

CH40: Poor Workmanship. The Oxford Dictionary defines it as "the relative finish or execution seen in the manufactured article." Poor workmanship has been cited as the major cause of leakage problems in construction sites [87].

CH41: Inadequate Payment. It is all about payment with delay or regardless of contract that causes dispute between construction staff and employer.

\section{Conflict of Interests}

The authors declare that there is no conflict of interests regarding the publication of this paper.

\section{Acknowledgment}

The authors would like to express their heartfelt gratitude to Dr. Hossein Moayedi, the editor, and the anonymous reviewers who have enhanced the contents of the present study significantly with their insightful comments. This work was financially supported by the eScienceFund (Project no. 06-0106-SF1198), Ministry of Science, Technology and Innovation of Malaysia (MOSTI), UTM Construction Research Centre, and Research Management Centre.

\section{References}

[1] P. M. Hillebrandt, "Problems of larger local contractors: causes and possible remedies," CIB REPORT, 1999.

[2] National University of Singapore Department of Building, 2010, http://www.bdg.nus.edu.sg/.

[3] CIOB, "Occupational stress in the construction industry," CIOB national stress survey results, 2006, http://www.ciob .org/sites/default/files/CIOB\%20research\%20-\%20Occupational\%20Stress\%20in\%20the\%20Construction\%20Industry\% 202006_0.pdf.

[4] A.-R. Abdul-Aziz and P. S. Jahn Kassim, "Objectives, success and failure factors of housing public-private partnerships in Malaysia," Habitat International, vol. 35, no. 1, pp. 150-157, 2011.

[5] A. Majid, M. Zaimi, and R. Zakaria, An effectiveness of communication in project undertaking: problems and constraints, 2001.

[6] I. Avots, "Why does project management fail? (Project management systems failure analysis, discussing cost, products quality and project objectives)," California Management Review, vol.12, pp. 77-82, 1969.

[7] A. A. L. Tan, People Skills in Project Management, Venton Publishing (M) Sdn. Bhd., Batu Caves, Malaysia, 2006.

[8] F. B. Razalli, Roles, skills and characteristics of project manger in construction industry [M.S. thesis], Faculty of Civil Engineering, Universiti Teknologi Malaysia, May 2007. 
[9] M. Hicks, "United States, Real Estate, Contract, Project Abandonment: Separate Legal Concepts," Mondaq, 2008, http://www .mondaq.com/unitedstates/article.asp?articleid $=60362$.

[10] R. Carrero, G. Malvárez, F. Navas, and M. Tejada, "Negative impacts of abandoned urbanisation projects in the Spanish coast and its regulation in the Law," Journal of Coastal Research, pp. 1120-1124, 2009.

[11] SPIEGEL, Architecture's Reality Check: Global Downturn Dooms Prestige Construction Projects, SPIEGEL ONLINE International, 2011, http://www.spiegel.de/international/business/0,1518,601523,00.html.

[12] A. Kabit, "Woes that cannot be abandoned," The Star Online, 2010, http://thestar.com.my/news/story.asp?file=/2010/ 8/28/focus/ $6887949 \&$ sec $=$ focus.

[13] L. M. A. Bettencourt and J. Kaur, "Evolution and structure of sustainability science," Proceedings of the National Academy of Sciences of the United States of America, vol. 108, no. 49, pp. 19540-19545, 2011.

[14] N. Heng, "Abandoned housing projects revisited," Sun2Surf, 2011, http://www.thesundaily.my/node/133203.

[15] MHLG (Ministry of Housing and Local Government), Perangkaan Terpilih KPKT Sehingga, Ministry of Housing and Local Government, 2012, http://www.kpkt.gov.my/kpkt/fileupload/perangkaan_terpilih/pt2012/sept/PROGRAM_PERUMAHAN.pdf.

[16] S. Rajoo, "The PAM 2006 standard form of building contract-a change in risk allocation," Malayan Law Journal, 2010.

[17] P.W.D Form 203. Standard form of contract to be used where drawings and specification form part of the contract, Rev., 2007.

[18] M. Leung, Y. Chan, and P. Olomolaiye, "Impact of stress on the performance of construction project managers," Journal of Construction Engineering and Management, vol. 134, no. 8, pp. 644-652, 2008.

[19] S. S. C. Liao, “Top ten qualities of project manager Heroes: an interview with David B. Perini," Leadership and Management in Engineering, vol. 7, no. 2, pp. 50-60, 2007.

[20] Z. Shehu and A. Akintoye, "Major challenges to the successful implementation and practice of programme management in the construction environment: a critical analysis," International Journal of Project Management, vol. 28, no. 1, pp. 26-39, 2010.

[21] D. Z. Milosevic, R. J. Martinelli, and J. M. Waddell, Program Management for Improved Business Results, John Wiley \& Sons, 2007.

[22] S. Cicmil, T. Williams, J. Thomas, and D. Hodgson, "Rethinking project management: researching the actuality of projects," International Journal of Project Management, vol. 24, no. 8, pp. 675-686, 2006.

[23] N. W. Young, "Key trends in the European and US construction market place," Smart Market Report, Design and Construction intelligence, CIOB, University of Reading and CRC, 2008.

[24] UK Construction Industry, Construction Industry News, "Industry Structure," 2005, http://www.cnplus.co.uk.

[25] B. Choi, S. K. Poon, and J. G. Davis, "Effects of knowledge management strategy on organizational performance: a complementarity theory-based approach," Omega, vol. 36, no. 2, pp. 235-251, 2008.

[26] OGC, Project management, 2007, http://www.ogc.gov.uk/delivery_lifecycle_project_management.asp.

[27] J. Bartlett, Managing Programmes of Business Change: A Handbook of the Principles of Programme Management, Project Manager Today Publications, 2002.
[28] M. Thiry, "“For DAD”: A programme management life-cycle process," International Journal of Project Management, vol. 22, no. 3, pp. 245-252, 2004.

[29] G. Reiss, Programme Management Demystified: Managing Multiple Projects Successfully, Resources/Publications, Spon Press, 2003.

[30] B.-G. Hwang and W. J. Ng, "Project management knowledge and skills for green construction: overcoming challenges," International Journal of Project Management, vol. 31, no. 2, pp. 272-284, 2013.

[31] E. Tagaza and J. L. Wilson, "Green buildings: drivers and barriers e lessons learned from five Melbourne developments," Tech. Rep., Building Commission by University of Melbourne and Business Outlook and Evaluation, 2004.

[32] X. Zhang, L. Shen, and Y. Wu, "Green strategy for gaining competitive advantage in housing development: a China study," Journal of Cleaner Production, vol. 19, no. 2-3, pp. 157-167, 2011.

[33] D. K. H. Chua, Y. Wang, and W. T. Tan, "Impacts of obstacles in East Asian cross-border construction," Journal of Construction Engineering and Management, vol. 129, no. 2, pp. 131-141, 2003.

[34] D. Eisenberg, R. Done, and L. Ishida, "Breakingdown the barriers: challenges and solutions to code approval of green building," Research Report, Development Center for Appropriate Technology, 2002, http://www.dcat.net/resources/breaking_down_barriers.pdf.

[35] I. Yitmen, "The challenge of change for innovation in construction: a North Cyprus perspective," Building and Environment, vol. 42, no. 3, pp. 1319-1328, 2007.

[36] M. Sexton and P. Barrett, "The role of technology transfer in innovation within small construction firms," Engineering, Construction and Architectural Management, vol. 11, no. 5, pp. 342348, 2004.

[37] K. N. Hewage, J. Y. Ruwanpura, and G. F. Jergeas, "IT usage in Alberta's building construction projects: current status and challenges," Automation in Construction, vol. 17, no. 8, pp. 940947, 2008.

[38] J. P. S. Siva and K. London, "Investigating the role of client learning for successful architect-client relationships on private single dwelling projects," Architectural Engineering and Design Management, vol. 7, no. 3, pp. 177-189, 2011.

[39] C. B. Tatum, "Integrated construction engineering activities to satisfy challenging project objectives," in Proceedings of the Construction Research Congress, Construction Challenges in a Flat World, pp. 139-148, ASCE, 2012.

[40] A. J. Hellmund, K. G. Van Den Wymelenberg, and K. Baker, "Facing the challenges of integrated design and project delivery," Strategic Planning for Energy and the Environment, vol. 28, no. 1, pp. 69-80, 2008.

[41] F. T. Mills and J. Glass, "The construction design manager's role in delivering sustainable buildings," Architectural Engineering and Design Management, vol. 5, no. 1-2, pp. 75-90, 2009.

[42] L. Bibby, S. Austin, and D. Bouchlaghem, "Design management in practice: testing a training initiative to deliver tools and learning," Construction Innovation, vol. 3, no. 4, pp. 217-229, 2003.

[43] C. A. Gorse and S. Emmitt, "Communication behaviour during management and design team meetings: a comparison of group interaction," Construction Management and Economics, vol. 25, no. 11, pp. 1195-1211, 2007.

[44] B. Hwang, S. R. Thomas, C. T. Haas, and C. H. Caldas, "Measuring the impact of rework on construction cost performance," 
Journal of Construction Engineering and Management, vol. 135, no. 3, pp. 187-198, 2009.

[45] T. Taib, Efficiency in construction process [Ph.D. thesis], Universiti Teknologi Malaysia, Faculty of Civil Engineering, 2010.

[46] M. Z. A. Majid, W. Z. Zakaria, and A. Keyvanfar, "Executive information site management system for monitoring project performance: system requirement study," OIDA International Journal of Sustainable Development, vol. 3, no. 3, pp. 11-24, 2012.

[47] R. M. Wideman, "Comparing PRINCE2 with PMBoK," 2002, http://www.pmforum.org/library/papers/ Prince2vsGuide3easrd1.htm.

[48] W. Belassi and O. I. Tukel, "A new framework for determining critical success/failure factors in projects," International Journal of Project Management, vol. 14, no. 3, pp. 141-151, 1996.

[49] L. Crawford, "Profiling the competent project manager," in Proceedings of the PMI Research Conference, pp. 3-15, Project Management Institute, June 2000.

[50] D. K. Ahadzie, A model for predicting the performance of project managers in mass house building projects in Ghana.

[51] T. Frank, The Superior Project Manager, Marcel Dekker, New York, NY, USA, 2002.

[52] M. A. Khan, Bridge and Highway Structure Rehabilitation and Repair, McGraw-Hill, 2010.

[53] M. Yadollahi and M. Z. Zin, "Development of analytical hierarchy process (AHP) method for rehabilitation project ranking before disasters," in Proceedings of the 2nd International Conference on Disaster Management and Human Health: Reducing Risk, Improving Outcomes, pp. 209-220, WIT Press, Orlando, Fla, USA, 2012.

[54] I. M. Shohet and E. Perelstein, "Decision support model for the allocation of resources in rehabilitation projects," Journal of Construction Engineering and Management, vol. 130, no. 2, pp. 249-257, 2004.

[55] T. Hegazy, "Optimization of resource allocation and leveling using genetic algorithms," Journal of Construction Engineering and Management, vol. 125, no. 3, pp. 167-175, 1999.

[56] PMBOK Guide, Project Management Body of Knowledge (PMBOK Guide), Project Management Institute, 2008.

[57] K. T. Odusami, "Perceptions of construction professionals concerning important skills of effective project leaders," Journal of Management in Engineering, vol. 18, no. 2, pp. 61-67, 2002.

[58] S. M. Benz, The Project Manager's CADD Survival Guide, ASCE Publications, 1997.

[59] B. G. Fryer and M. Fryer, The Practice of Construction Management, BSP Professional, 1990.

[60] T. Ceran and A. A. Dorman, "The complete project manager," Journal of Architectural Engineering, vol. 1, no. 2, pp. 67-72, 1995.

[61] L. Holmes and P. Joyce, "Rescuing the useful concept of managerial competence: from outcomes back to process," Personnel Review, vol. 22, no. 6, pp. 37-52, 1993.

[62] S. E. Abraham, L. A. Karns, K. Shaw, and M. A. Mena, "Managerial competencies and the managerial performance appraisal process," The Journal of Management Development, vol. 20, no. 10, pp. 842-852, 2001.

[63] M. Z. A. Majid, W. Z. Zakaria, and A. Keyvanfar, "Executive information site management system for monitoring project performance: system requirement study," OIDA International Journal of Sustainable Development, vol. 3, no. 3, pp. 11-24, 2012.

[64] S. K. Sears, G. A. Sears, and R. H. Clough, Construction Project Management: A Practical Guide to Field Construction Management, Wiley, Hoboken, NJ, USA, 5th edition, 2008.
[65] K. N. Hewage, J. Y. Ruwanpura, and G. F. Jergeas, "IT usage in Alberta's building construction projects: current status and challenges," Automation in Construction, vol. 17, no. 8, pp. 940947, 2008.

[66] S. Bertelsen, K. Fuhr Petersen, and H. Davidsen, The Client as Agent for Changes-Towards a New Culture in Building, Bygherreforeningen Danmark, Fonden Realdania, Byggecentrum, Denmark, 2002.

[67] K. B. Khoury, Communication in architecture project management: the case of architecture firms in Lebanon, [A thesis submitted in partial fulfillment of the requirements for the degree of Doctor of Business Administration], Grenoble Ecole de Management, 2012.

[68] E. Adinyira and C. A. Dafeamekpor, "Clients' perceptions of architect performance on building projects in Ghana," of Professional Issues in Engineering Education \& Practice, 2014.

[69] Necessity of an Architect During Construction (NCARB), National Council of Architectural Registration Boards, Washington, DC, USA, 20006-1310, December 2010, http://www .ncarb.org/.

[70] S. Ogunlana, Z. Siddiqui, S. Yisa, and P. Olomolaiye, "Factors and procedures used in matching project managers to construction projects in Bangkok," International Journal of Project Management, vol. 20, no. 5, pp. 385-400, 2002.

[71] J. Wateridge, "How can IS/IT projects be measured for success?" International Journal of Project Management, vol. 16, no. 1, pp. 59-63, 1998.

[72] Y. S. Lincoln and E. Guba, Naturalistic Inquiry, Sage, Beverly Hills, Calif, USA, 1985.

[73] F. Adam and P. Humphreys, Encyclopedia of Decision Making and Decision Support Technologies, United States of America, Information Science Reference, 2008.

[74] W. A. Belson, Validity in Survey Research, Gower, Aldershot, UK, 1986.

[75] L. Cohen, L. Manion, and K. Morrison, Research Methods in Education, Routledge, Taylor \& Francis, New York, NY, USA, 6th edition, 2007.

[76] R. E. Bellman and L. A. Zadeh, "Decision-making in a fuzzy environment," Management Science, vol. 17, no. 4, pp. 141-164, 1970.

[77] L. Shen, W. Lu, Y. Peng, and S. Jiang, "Critical assessment indicators for measuring benefits of rural infrastructure investment in China," Journal of Infrastructure Systems, vol. 17, no. 4, pp. 176-183, 2012.

[78] B. Xia, A. P. C. Chan, and J. F. Y. Yeung, "Developing a fuzzy multicriteria decision-making model for selecting design-build operational variations," Journal of Construction Engineering and Management, vol. 137, no. 12, pp. 1176-1184, 2011.

[79] H. J. Zimmermann, Fuzzy Set Theory and Its Applications, Kluwer Academic, London, UK, 4th edition, 2001.

[80] T. Tervonen, J. R. Figueira, R. Lahdelma, J. A. Dias, and P. Salminen, "A stochastic method for robustness analysis in sorting problems," European Journal of Operational Research, vol. 192, no. 1, pp. 236-242, 2009.

[81] P. A. Bowen, K. S. Cattel, K. A. Hall, P. J. Edwards, and R. G. Pearl, "Perceptions of time, cost and quality management on building projects," Australasian Journal of Construction Economics and Building, vol. 2, no. 2, pp. 48-56, 2012.

[82] R. H. Katz, “Managing the chip design database," Computer, vol. 16, no. 12, pp. 26-36, 1983. 
[83] B. Sandoval, D. Mangus, and B. Samuels, Heritage Comics Auctions, 2005 Random House Archives Catalog\# 816, Heritage Capital Corporation, 2005.

[84] D. Clark, Big Dog's Leadership Page, 1997, http://www.nwlink .com/ donclark/leader/leadcon.html.

[85] M. E. L. Hoezen, I. M. M. J. Reymen, and G. P. M. R. Dewulf, "The problem of communication in construction," in Proceedings of the CIB W06 Adaptables Conference, Eindhoven, The Netherlands, 2006.

[86] M. T. Callahan, B. B. Bramble, and F. M. Rapoport, Discovery in Construction Litigation, Michie Company, 1987.

[87] J. I. Davison, Workmanship and Rain Penetration of Masonry Walls, Atlantic Regional Station, Division of Building Research, National Research Council of Canada, 1980, http://archive.nrccnrc.gc.ca/obj/irc/doc/pubs/bpn/16_e.pdf. 

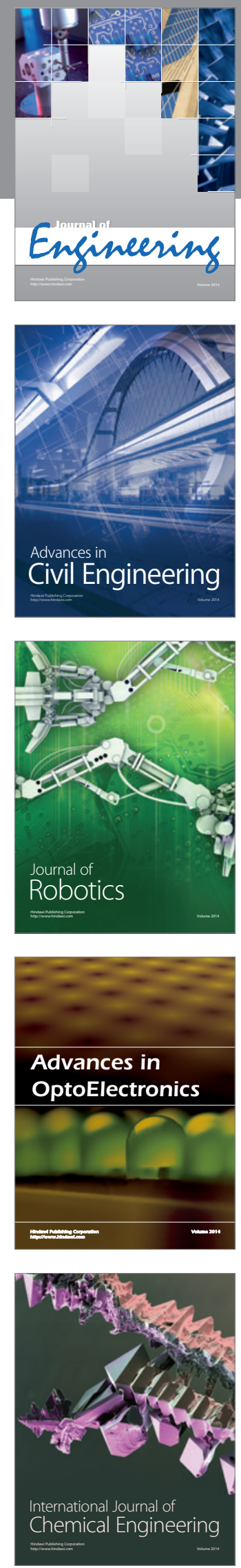

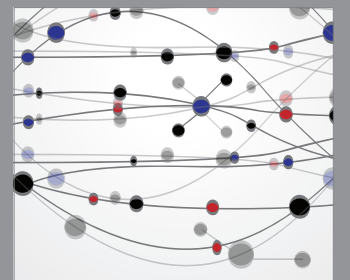

The Scientific World Journal
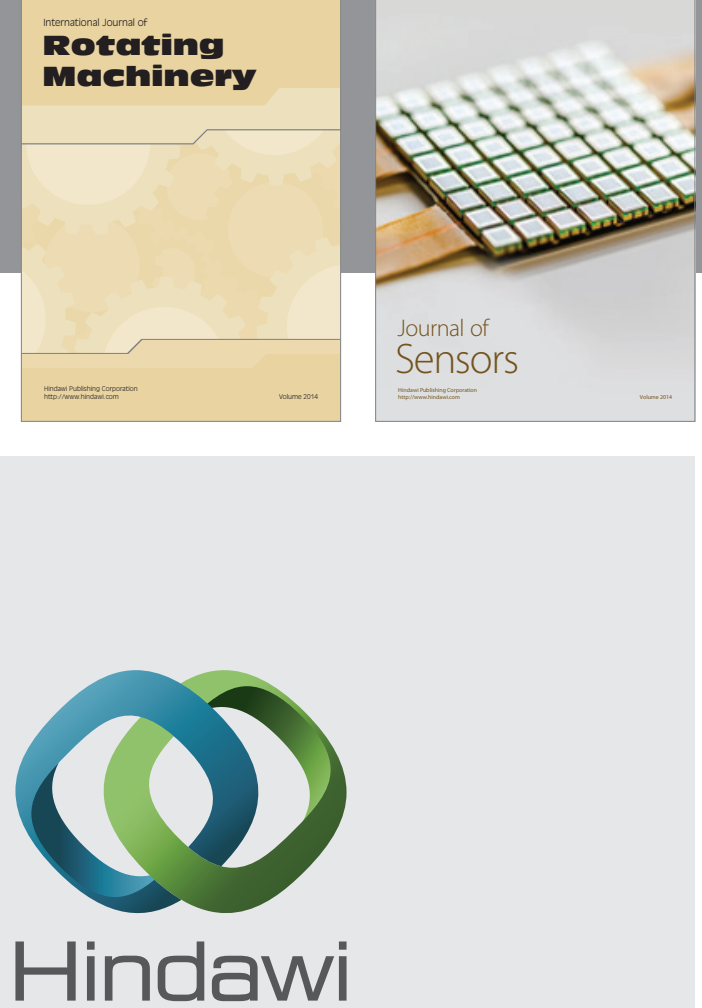

Submit your manuscripts at http://www.hindawi.com
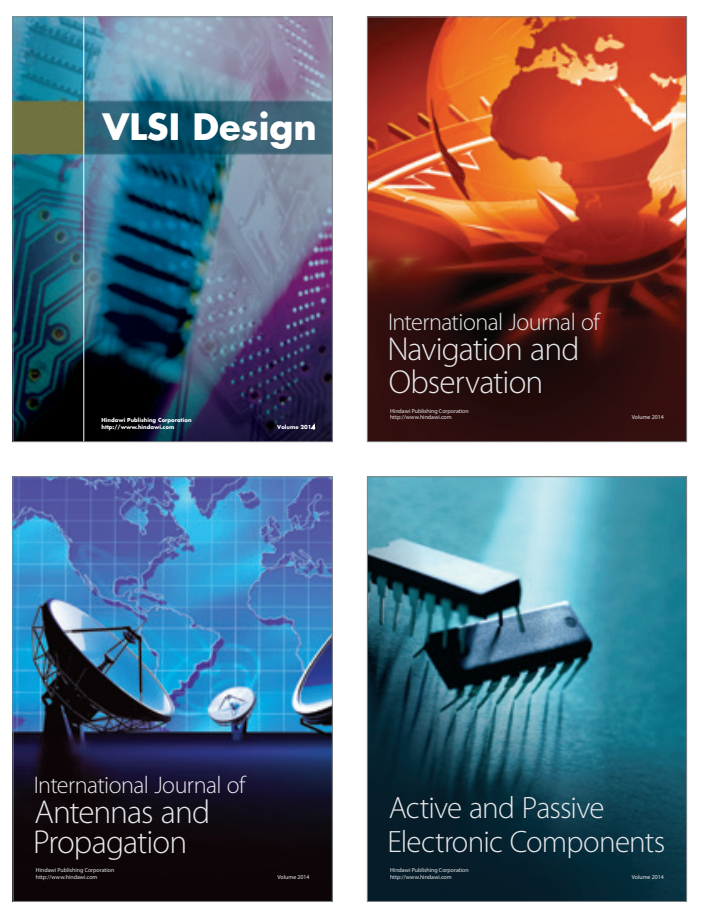
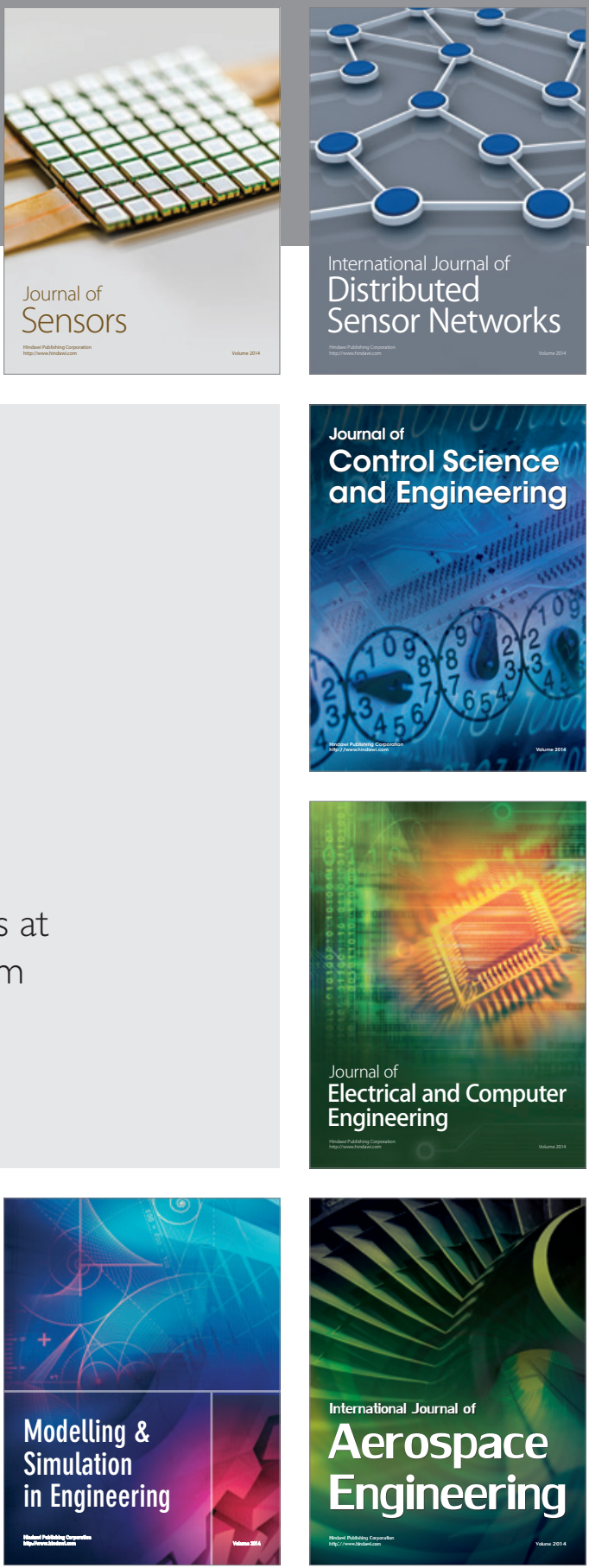

Journal of

Control Science

and Engineering
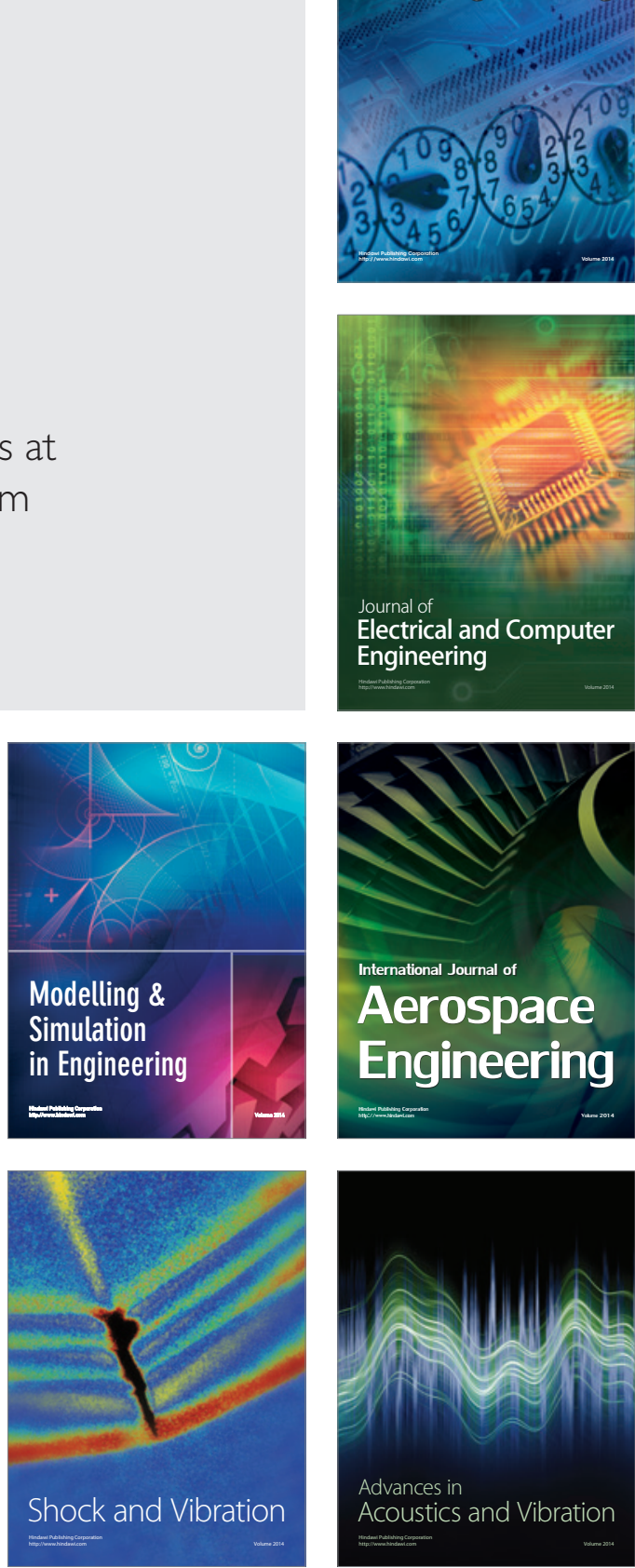